\title{
Tolerance of Basil Genotypes to Salinity
}

\author{
Renata V. Menezes ${ }^{1}$, André D. Azevedo Neto ${ }^{2}$, Hans R. Gheyi ${ }^{1}$, Alide M. W. Cova ${ }^{1} \&$ Hewsley H. B. Silva ${ }^{1}$ \\ ${ }^{1}$ Centro de Ciências Agrárias, Ambientais e Biológicas, Universidade Federal do Recôncavo da Bahia, Cruz das \\ Almas, Brazil \\ ${ }^{2}$ Centro de Ciências Exatas e Tecnológicas, Universidade Federal do Recôncavo da Bahia, Cruz das Almas, \\ Brazil \\ Correspondence: André D. Azevedo Neto, Centro de Ciências Exatas e Tecnológicas, Universidade Federal do \\ Recôncavo da Bahia, R. Rui Barbosa, 710, Centro, Cruz das Almas, BA, CEP: 44380-000, Brazil. Tel: \\ 55-75-3621-9362. E-mail: andre@ufrb.edu.br
}

Received: September 3, 2017

Accepted: September 30, $2017 \quad$ Online Published: October 15, 2017

doi:10.5539/jas.v9n11p283

URL: https://doi.org/10.5539/jas.v9n11p283

The research is financed by Coordenação de Aperfeiçoamento de Pessoal de Nível Superior (CAPES), Universidade Federal do Recôncavo da Bahia (UFRB).

\begin{abstract}
Basil (Ocimum basilicum L.) is a medicinal species of Lamiaceae family, popularly known for its multiple benefits and high levels of volatile compounds. The species is considered to be one of the most essential oil producing plants. Also cultivated in Brazil as a condiment plant in home gardens. The objective of this study was to evaluate the effect of salinity on the growth of basil in nutrient solution of Furlani and to identify variables related to the salinity tolerance in this species. The first assay was performed with variation of five saline levels ( 0 - control, 20, 40, 60 and $80 \mathrm{mM} \mathrm{NaCl}$ ). In the second assay six genotypes were evaluated in two salinity levels 0 and $80 \mathrm{mM} \mathrm{NaCl}$. The height, stem diameter, number of leaves, dry mass and inorganic solutes in different organs, photosynthetic pigments, absolute membrane integrity and relative water content were evaluated. All biometric variables in basil were significantly reduced by salinity. Dry matter yield and percentage of membrane integrity were the variables that best discriminated the characteristics of salinity tolerance among the studied basil genotypes. Basil genotypes showed a differentiated tolerance among the genotypes, the 'Toscano folha de alface' being considered as the most tolerant and 'Gennaro de menta' as the most sensitive, among the species studied.
\end{abstract}

Keywords: biomass, saline stress, membrane integrity, Ocimum basilicum $\mathrm{L}$.

\section{Introduction}

Basil (Ocimum basilicum L.) is a plant of the family Lamiaceae, a producer of essential oils of pharmaceutical importance, food, perfumery and cosmetics. It is also widely used in traditional medicine (Bharti, Barnawal, Wasnik, Tewari, \& Kalra, 2016). The species is cultivated on a commercial scale in Asia, Africa, South America and the Mediterranean region, under natural conditions or in protected cultivation. The cultivation in greenhouses has the advantages of maximizing the yield and allowing a constant supply of material throughout the year (Sgherri, Cecconami, Pinzino, Navari-Izzo, \& Izzo, 2010).

The use of brackish water in irrigation can result in soil salinization and compromise plant growth. The productivity of the crops in a salinized environment depends on the amount of soluble salts and the capacity of the plants to tolerate saline stress (Cova, Azevedo Neto, Ribas, Gheyi, \& Menezes, 2016). The reduction of the water potential in the culture medium, due to the higher concentration of soluble salts, affects the water absorption and, consequently, the turgescence and the cellular expansion. Moreover, saline stress also leads to a reduction of photosynthesis by the closure of the stomata and, therefore, limits the absorption of carbon dioxide and, consequently, the reduction of growth and productivity occurs (Farooq, Wahid, Kobayashi, Fujita, \& Basra, 2009).

In saline soils the main ions found are $\mathrm{Na}^{+}$and $\mathrm{Cl}^{-}$, which when absorbed and accumulated in excess may contribute to osmotic adjustment or become toxic (Flowers, Munns, \& Colmer, 2015). Thus, the ionic 
homeostasis between $\mathrm{K}^{+}$and $\mathrm{Na}^{+}$is fundamental for the regulation of the cellular osmotic potential (Zhu, 2003) and to avoid the deleterious effects of saline stress.

The integrity of cell membranes, enzymatic activity and photosynthesis are metabolic and physiological indicative functions of tolerance variation in the species as they are sensitive to salinity. In order to evaluate the tolerance of plants to salinity, growth is considered to be an effective measure as it integrates a set of physiological mechanisms that occur in the plant (Niknam \& McComb, 2000). Tolerant plants may have ionic compartmentation mechanisms, while in sensitive plants this mechanism is not efficient. Plant responses to saline stress are complex and may vary between cultivars of the same species (Maas \& Hoffman, 1977; Niknam $\& \mathrm{McComb}, 2000)$. The genotypic variability may provide a differential tolerance to saline stress between plants from the same species, as evidenced by several authors (Azevedo Neto, Pereira, Costa, \& Santos, 2011).

Knowing that basil is a very important crop, the objective of the present study was to evaluate the tolerance of six basil genotypes to saline stress and to classify them according to the degree of tolerance to stress.

\section{Material and Methods}

The study was conducted in a protected environment at the Federal Universidade do Recôncavo da Bahia, Centro de Ciências Exatas e Tecnológica, Cruz das Almas-BA (12 40 $10^{\prime} 19^{\prime \prime}$ S 396 $6^{\prime 2} 3^{\prime \prime}$ W), from January to March 2015. Two experiments were carried out: the first one was a completely randomized design with five saline levels and four replicates and the second one was a randomized block design with two saline levels and six genotypes with four replicates.

\subsection{Assay I: Experimental Conditions and Treatments}

Basil seeds var. Alfavaca basilicão, obtained at ISLA Sementes Ltda. were seeded in $150 \mathrm{~mL}$ plastic cups containing washed sand. At 21 days after emergence (DAE), when the seedlings presented a completely expanded pair of leaves, they were transferred to containers in a hydroponic "Floating" type system with aeration, containing $12 \mathrm{~L}$ of nutrient solution of Furlani (1998). After four days under these conditions, the seedlings received their respective saline treatments $0,20,40,60$ or $80 \mathrm{mM} \mathrm{NaCl}$, corresponding to electrical conductivities of the nutrient solution of $2,4,6,8$ and $10 \mathrm{dS} \mathrm{m}^{-1}$. NaCl was gradually added $\left(20 \mathrm{mM}^{-1}\right)$, to avoid osmotic shock. The volume of the solutions was completed daily with water and the $\mathrm{pH}$ maintained between 6.0 and 6.5 by the addition of $\mathrm{HCl}$ or $\mathrm{NaOH}$. Plants were harvested 17 days after the treatments were applied.

\subsubsection{Biometry and Dry Mass Production}

The height of the plants, stem diameter (SD) and number of leaves (NL) were determined at the harvest. The height was measured with a graduated ruler, the main branch was measured from $0.5 \mathrm{~cm}$ from the insertion of the root to the apex of the main branch. The SD was measured with a digital caliper and counted the NL. Afterwards, the plants were collected and separated in leaves, stems and roots and the plant material was transferred to an oven with forced air circulation at $65^{\circ} \mathrm{C}$ for $72 \mathrm{~h}$. After this period, the determination of dry masses of leaf (LDM), stem (SDM) and roots (RDM) was performed on a precision scale. From the dry mass data of the plant parts, shoot dry mass (SHDM) and total dry mass (TDM) were calculated.

\subsubsection{Analysis of Inorganic Solutes}

For the determination of $\mathrm{Na}^{+}, \mathrm{K}^{+}$and $\mathrm{Cl}^{-}$contents in leaves, stems and roots, the extracts were prepared as described by Jones Júnior (2001), with minor modifications. In test tubes, $0.1 \mathrm{~g}$ of dried (in oven) and powdered material (in Willye-type knife mill) and $10 \mathrm{~mL}$ of deionized water were added. The test tubes were heated at $80^{\circ} \mathrm{C}$ in a water bath for $1 \mathrm{~h}$, being agitated every $15 \mathrm{~min}$ and then centrifuged at $5.000 \times \mathrm{g}$. The supernatant was collected and stored at $-20{ }^{\circ} \mathrm{C}$ for further analysis. The $\mathrm{Na}^{+}$and $\mathrm{K}^{+}$contents were determined by flame photometry (Faithfull, 2002) and the values of $\mathrm{Cl}^{-}$by spectrophotometry (Jones Júnior, 2001).

\subsection{Assay II: Treatment and Execution}

In the second assay, seeds of genotypes 'Gennaro de Menta', 'Alfavaca basilicão vermelho', 'Alfavaca basilicão', 'Toscano folha de alface', 'Limocino' and 'Grecco a palla', obtained from the company ISLA Sementes Ltd., were used. The seedlings production and the cultivation system were identical to Assay I. The seedlings of each genotype were submitted to 0 and $80 \mathrm{mM}$ of $\mathrm{NaCl}$ in nutrient solution of Furlani (1998), with electrical conductivities of 2 and $10 \mathrm{dS} \mathrm{m}^{-1}$, respectively. Addition of $\mathrm{NaCl}$ and control of nutrient solutions were also identical to those of Assay I. Plants were harvested after 20 days after the treatments were applied. 


\subsubsection{Dry Mass Production and Analysis of Inorganic Solutes}

At the end of the experimental period, the plants were separated into leaves, stems and roots to evaluate dry mass and determination of $\mathrm{Na}^{+}, \mathrm{K}^{+}$and $\mathrm{Cl}^{-}$contents according to Experiment $\mathrm{I}$.

\subsubsection{Photosynthetic Pigments}

To determine the levels of chlorophyll $a$, chlorophyll $b$ and carotenoids (carotenes and xanthophyll), the samples were placed in 95\% ethanol. Then, the spectrophotometric readings were performed at 649, 664 and $470 \mathrm{~nm}$, according to the methodology described by Lichtenthaler and Buschmann (2001) and were calculated with Equations 1, 2 and 3, respectively:

$$
\begin{gathered}
\text { CHLa }\left(\mu \mathrm{g} \mathrm{ml}^{-1}\right)=\left(13.36 \times \mathrm{A}_{664}-5.19 \times \mathrm{A}_{649}\right) \\
\operatorname{CHL} b\left(\mu \mathrm{g} \mathrm{ml}^{-1}\right)=\left(27.43 \times \mathrm{A}_{649}-8.12 \times \mathrm{A}_{664}\right) \\
\operatorname{Car}\left(\mu \mathrm{g} \mathrm{ml}^{-1}\right)=\left(1000 \times \mathrm{A}_{470}-2.13 \times \mathrm{CHL} a-97.64 \times \mathrm{CHL} b\right) / 209
\end{gathered}
$$

\subsubsection{Absolute Integrity Percentage (AIP) of Cell Membranes and Relative Water Content (RWC)}

The AIP and RWC evaluations were performed on the third fully expanded leaf pair, for all genotypes except for 'Grecco a palla', where they were determined in the main branch, adapting the methodology to the morphology of this genotype. The determination of AIP was performed according to Pimentel, Sarr, Diouf, Aboud, and Roy-Macauley (2002), where 10 leaf discs with known area were placed in threaded tubes with $10 \mathrm{~mL}$ of deionized water. The tubes were placed for $24 \mathrm{~h}$ in a dark place and after that the electrical conductivity of the water (free conductivity- FC) was measured. Afterwards, the tubes were placed in a water bath at $100{ }^{\circ} \mathrm{C}$ for one hour and after returning to the ambient temperature the electrical conductivity of the water (total conductivity TC) was again measured. It was calculated using Equation 4:

$$
\operatorname{AIP}(\%)=100-(\mathrm{FC} \times 100 / \mathrm{TC})
$$

The RWC was determined according to Barr and Watherley (1962), in which 10 leaf discs with known area were removed and weighed to obtain the fresh mass (FM). The disks were then placed in Petri dishes, immersed in deionized water and left for 24 hours in a refrigerator. After this period, the discs were wiped with paper towel and weighed to obtain the turgid mass (TM). Afterwards, they were taken to dry in an oven until constant weight was obtained. The RWC was calculated as described in Equation 5:

$$
\mathrm{RWC}(\%)=[(\mathrm{DM}-\mathrm{FM}) /(\mathrm{DM}-\mathrm{TM})] \times 100
$$

\subsubsection{Statistical Analysis}

For the first assay, the results were submitted to analysis of variance (F test) and regression, using the Sisvar 4.6 statistical software (Ferreira, 2011). In the second assay, the results were submitted to analysis of variance (F-test) and the means compared by the Scott-Knott test at 0.05 probability.

\section{Results and Discussion}

\subsection{Assay I}

The variables plant height, stem diameter (SD) and number of leaves (NL) presented linear decreasing behavior with the increment of sodium chloride in the nutrient solution (Figure 1). Comparing the control treatment with the one using $80 \mathrm{mM} \mathrm{NaCl}$, reductions of 37.31 and $27.5 \%$ were observed for height, SD and NL, respectively. 

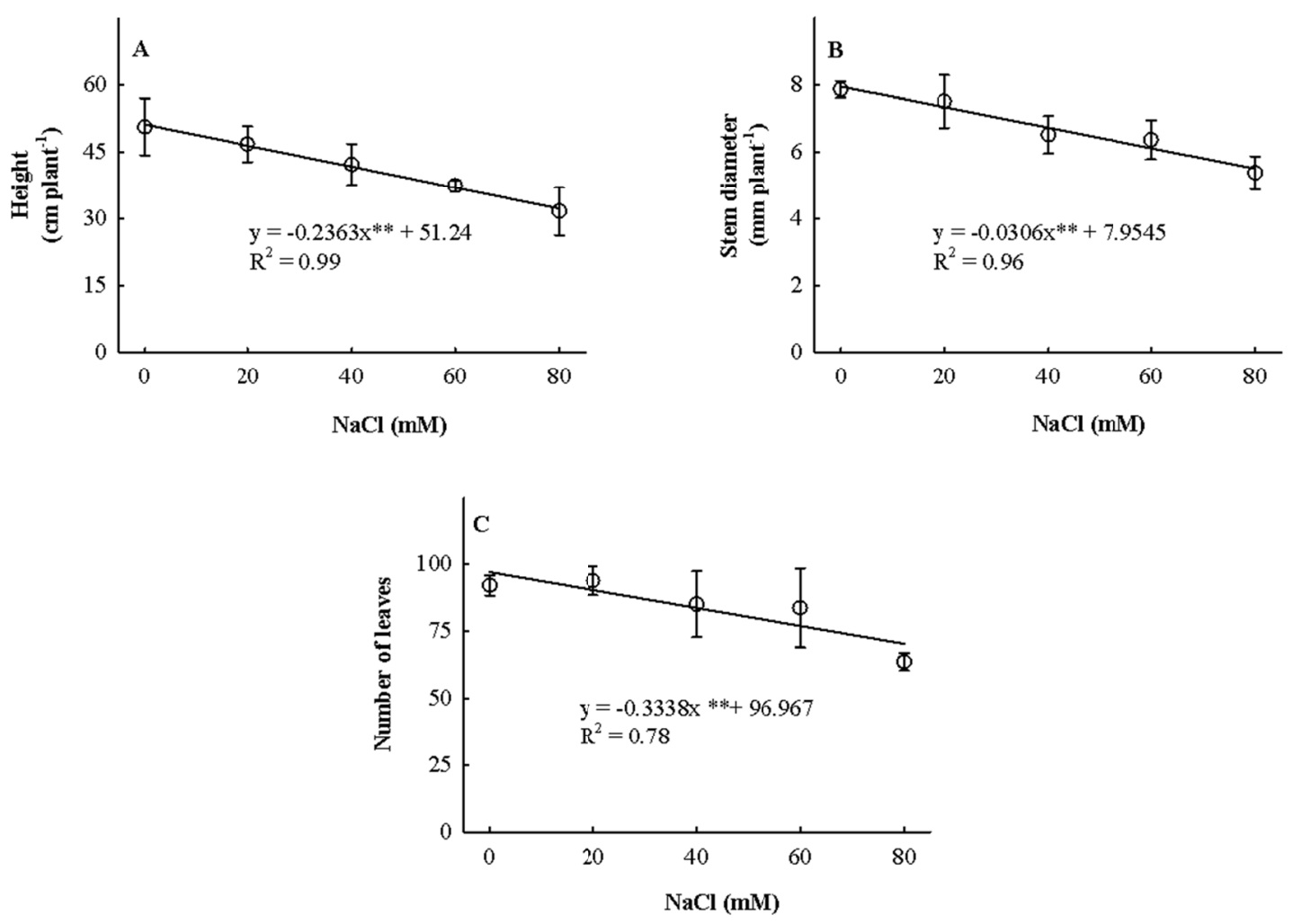

Figure 1. Height (A), stem diameter (B) and number of leaves (C) of basil plants 17 days after treatment in nutrient solution containing increasing levels of $\mathrm{NaCl}$

Note. Values indicate means of four replicates and respective standard deviations.

The diameter of the stem was reduced from 7.95 to $5.51 \mathrm{~mm}$. Stem diameter is an important variable in cultivation without soil, as it is responsible for the support of the aerial part thus, if too thin, it may result in plant lodging.

For NL the reduction was from 97 to 70 leaves per plant with increased salinity in the nutrient solution (Figure 1C). The leaves are reserve storage sites, sources of hormones and other plant compounds and it is the location for the photosynthetic apparatus. Therefore, a reduction in $\mathrm{NL}$ is related to a reduction in $\mathrm{CO}_{2}$ absorption and biomass production.

Several factors may be associated with the reduction of plant growth when submitted to saline stress, such as the low osmotic potential of the solution, the interaction of specific ions, nutritional imbalances or a combination of these factors (Parida \& Das, 2005; Marschner, 2012). The osmotic potential of saline environment reduces the ability of plants to absorb water, which affects the physiological processes and inhibits meristematic activity, elongation and cell division, which results in a rapid reduction in growth rate and biomass production (Ayers \& Westcot, 1999; Munns, 2002; Parida \& Das, 2005).

The salinity increase in the nutrient solution also linearly reduced the dry mass production in the different organs (Figure 2). The LDM and RDM showed reductions of 0.027 and $0.008 \mathrm{~g}$ per unit increase of $\mathrm{mM} \mathrm{NaCl}$, respectively. The SDM presented a mathematical adjustment to the quadratic model (Figure 2B), the estimated data for the minimum SDM was $0.25 \mathrm{~g}(80 \mathrm{mM} \mathrm{NaCl})$ and the maximum was $2.08 \mathrm{~g}(0 \mathrm{mM} \mathrm{NaCl})$. For SHDM and TDM this reduction was 0.044 and $0.051 \mathrm{~g}$, respectively. Thus, the estimated reductions were $58,88,47,56$ and $55 \%$ for LDM, SDM, RDM, SHDM and TDM, respectively, indicating that the aerial part of the plant was more sensitive to salinity than the roots. As the reduction of dry mass production in the different parts of the plants were similar, SHDM/RDM values were not affected by salinity, presenting a mean value of approximately 4.5 (Figure 2E). 


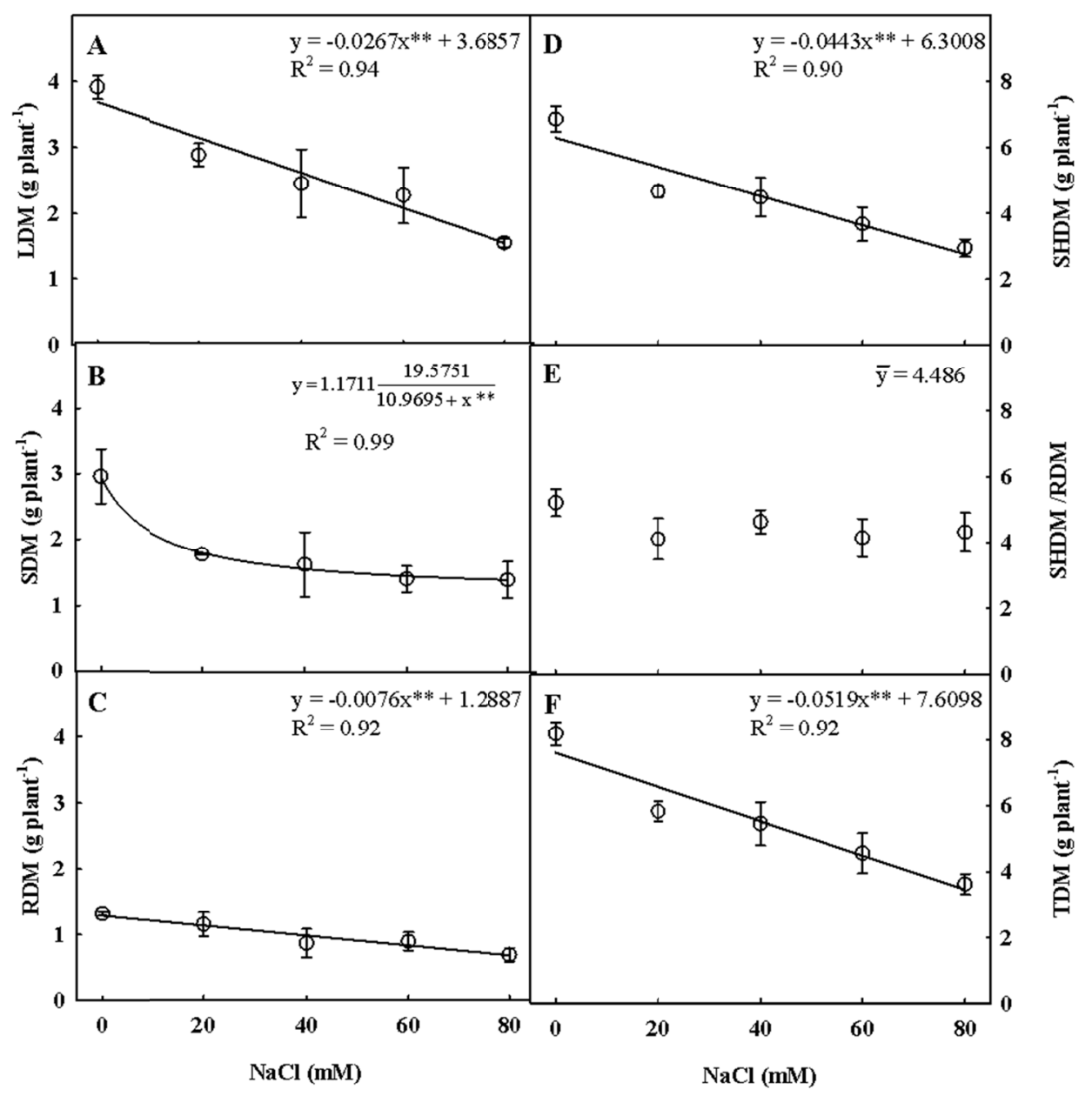

Figure 2. Leaf dry mass - LDM (A), stem dry mass - SDM (B), root dry mass - RDM (C), shoot dry mass SHDM (F) and shoot dry mass ratio by root dry mass - SHDM/RDM (E), in basil plants 17 days after treatment in nutrient solution containing increasing levels of $\mathrm{NaCl}$

Note. Values indicate means of four replicates and respective standard deviations.

Bione et al. (2014) in studies with basil, observed a reduction of $0.0786 \mathrm{~g}$ in SHDM for each unit increment in $\mathrm{dS} \mathrm{m}^{-1}$, where $8.48 \mathrm{dS} \mathrm{m}^{-1}$ was the maximum level of electrical conductivity. Paulus, Dourado Neto, Frizzone, and Soares (2010) and Santos, Soares, A. N. Silva, E. F. F. Silva, and Montenegro (2010), in studies with lettuce hydroponic cultivation, also reported a linear reduction in SHDM with increased saline levels. The reduction in dry mass production might be a reflection of the metabolic energy cost associated with acclimatization to saline stress and reduction in carbon gain (Atkin \& Macherel, 2009). Therefore, there is a reduction in the supply of photoassimilates and plant hormones to growing tissues (Munns, 1993), which may be related to the dry mass reduction of basil different organs. As already mentioned above, another factor that affects the growth of plants under saline stress is the osmotic effect, which restricts the absorption and transport of water. Such restriction triggers a sequence of hormone-mediated reactions and consequently reducing stomatal aperture and photosynthetic assimilation of $\mathrm{CO}_{2}$ and biomass production (Odjegba \& Chukwunwike, 2012; S. L. F. Silveira, Silva, E. N. Silva \& Viégas, 2010).

The $\mathrm{Cl}^{-}$and $\mathrm{Na}^{+}$contents increased linearly in all parts of the plant with the addition of $\mathrm{NaCl}$ in the nutrient solution (Figure 3). The contents of $\mathrm{Cl}^{-}$in leaves, stem and roots presented increments of $0.01 ; 0.008$ and 0.005 mmol g${ }^{-1} \mathrm{DM}$, respectively, per $\mathrm{mM} \mathrm{NaCl}$ in the nutrient solution (Figures $3 \mathrm{~A}, 3 \mathrm{~B}$ and $3 \mathrm{C}$ ). Thus, the contents of this ion in leaves, stem and roots increased 5.15, 3.15 and 2.97 times respectively, when compared to the control treatment $(0 \mathrm{mM} \mathrm{NaCl})$ at the highest saline treatment $(80 \mathrm{mM} \mathrm{NaCl})$. 


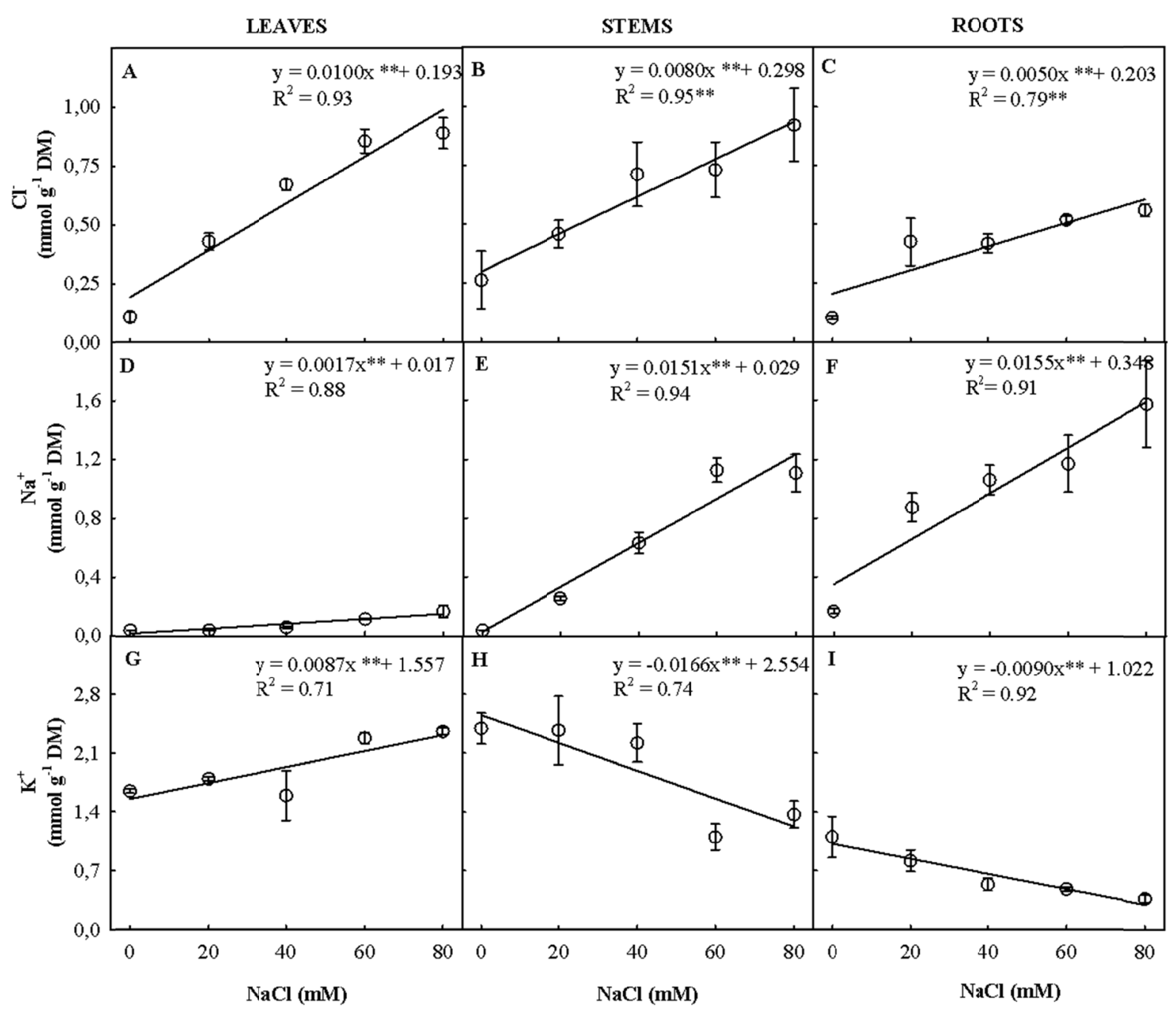

Figure 3. Chloride - $\mathrm{Cl}^{-}$, sodium $-\mathrm{Na}^{+}$and potassium - $\mathrm{K}^{+}$contents in leaves (A, D and G), stems $(\mathrm{B}, \mathrm{E}$ and $\mathrm{H})$ and roots $(\mathrm{C}, \mathrm{F}$ and $\mathrm{I})$ in basil plants 17 days after treatment in nutrient solution containing levels of $\mathrm{NaCl}$

Note. Values indicate means of four replicates and respective standard deviations.

Among the growth variables and dry masses analyzed, DM was the most accurate indicator of the salinity effect, corroborating with chloride accumulation data. Therefore, a larger reduction of DM occurred in the tissues with the highest $\mathrm{Cl}^{-}$accumulation (leaves and stems), as the smallest reduction of DM was in the root, where less accumulation of this ion occurred.

The estimated concentrations of $\mathrm{Na}^{+}$at concentrations of 0 and $80 \mathrm{mM} \mathrm{NaCl}$ ranged from 0.017 to $0.153 \mathrm{mmol}$ $\mathrm{g}^{-1}$ for LDM, from 0.029 to $1.237 \mathrm{mmol} \mathrm{g}^{-1}$ for SDM and from 0.348 to $1.588 \mathrm{mmol} \mathrm{g}^{-1}$ for RDM (Figures 3D, $3 \mathrm{E}$ and $3 \mathrm{~F}$ ). Thus, there was a higher retention of this ion in the roots, when compared to the leaves and stem, Ning et al. (2015) found similar results. $\mathrm{Na}^{+}$retention in the root helps to maintain $\mathrm{Na}^{+} / \mathrm{K}^{+}$ratios required for normal cellular functions and prevents toxic accumulation of this ion in the leaves (Shabala \& Mackay, 2011).

The increase of $\mathrm{NaCl}$ in the nutrient solution increased linearly the $\mathrm{K}^{+}$content in the leaves and decreased linearly in the stem and roots (Figures $3 \mathrm{G}, 3 \mathrm{H}$ and $3 \mathrm{I}$ ). With the escalation of salinity in the nutrient solution, the $\mathrm{K}^{+}$ion increased $45 \%$ in the leaves and decreased in the stem and in the roots $52 \%$ and $70 \%$, respectively in relation to the control treatment. Thus, we can affirm that as salinity increased, there was a translocation of $\mathrm{K}^{+}$to the leaves in detriment of the other parts.

The highest reductions in $\mathrm{K}^{+}$levels were observed in the tissues with the highest $\mathrm{Na}^{+}$accumulation. These ions compete for the same entry sites in cells, having an antagonistic relationship in plasma membrane uptake 
(Marschner, 2012). These results suggest a higher selectivity of $\mathrm{K}^{+}$ion transport in relation to $\mathrm{Na}^{+}$for the leaves, as well as a mechanism of $\mathrm{Na}^{+}$retention in stem and root tissues, avoiding damage due to toxicity in the leaves.

The osmotic adjustment, that is, the accumulation of solutes is an important mechanism, under conditions of saline stress, to obtain a gradient of favorable water potential and maintenance of cellular turgor. The accumulation of the inorganic solutes $\left(\mathrm{K}^{+}, \mathrm{Na}^{+}\right.$and $\left.\mathrm{Cl}^{-}\right)$has a lower energy cost for the cells when related to the accumulation of compatible organic solutes (Flowers, Munns, \& Colmer, 2015). However, there must be a balance between these ions, because $\mathrm{Cl}^{-}$and $\mathrm{Na}^{+}$can be toxic when in excess in plant tissues. In this way, the accumulation of $\mathrm{K}^{+}$favors ionic homeostasis, reducing the toxic effects of $\mathrm{Na}^{+}$(Munns \& Tester, 2008).

Among all the variables studied in Assay I, the DM variable was the most accurate indicator of salinity effect, associated with the $\mathrm{Cl}^{-}$accumulation data. In this way, a larger reduction of DM occurred in the tissues with higher $\mathrm{Cl}^{-}$accumulation (leaves and stems) and, as the smallest DM reduction was in the root, where there was less accumulation of DM. The $\mathrm{Cl}^{-}$is a predominant anion under saline conditions (Tavakkoli, Rengasamy, \& McDonald, 2010), when absorbed by the roots is easily translocated to the tissues of the aerial part (Li, Tester, \& Gilliham, 2017), justifying its large accumulation in leaves and roots.

In this study, it is considered that $80 \mathrm{mM} \mathrm{NaCl}$ significantly decreased (50 to $60 \%$ ) the dry mass production of basil organs in Assay I, this concentration was used for the subsequent salt stress experiments.

\subsection{Assay II}

Salinity reduced significantly the dry matter yield of leaf (LDM), stem (SDM), roots (RDM) and total (TDM) of basil genotypes, except for the 'Toscano folha de alface' (Figure 4). The highest reductions of LDM (54\%), SDM (71\%), RDM (55\%) and TDM (61\%) were observed in the 'Gennaro de menta' genotype. The reduction percentage in biomass production has been considered an effective indicator of tolerance to salt stress in plants (Munns, 2002). These data indicate that the 'Toscano folha de alface' genotype was more tolerant and the Gennaro de menta the most sensitive to salt stress when compared to each other (Figure 4).

The results of this study corroborate with the studies of Barbieri et al. (2012) and Prasad, Lal, Chattopadhyay, V. K. Yadav and A. Yadav (2007), who reported genotypic variability of basil in tolerance to saline stress. Barbieri et al. (2012) verified that the differentiated tolerance among the genotypes of this species was related to the morphological, physiological and metabolic adaptive characteristics to stress.

The $\mathrm{Na}^{+}$levels in the leaves (Figure 5A) of all basil genotypes were lower than in the stem (Figure 5B) and in the roots (Figure 5C). A significant variation might be observed between the mean values in the genotypes related to the rates of $\mathrm{Na}^{+}$in leaves $\left(0.126\right.$ to $\left.0.337 \mathrm{mmol} \mathrm{g}{ }^{-1} \mathrm{DM}\right)$, stem $\left(1.814\right.$ to $\left.3.414 \mathrm{mmol} \mathrm{g}^{-1} \mathrm{DM}\right)$ and roots ( 2.338 to $\left.3.720 \mathrm{mmol} \mathrm{g}{ }^{-1} \mathrm{DM}\right)$. It is interesting to note that the $\mathrm{Na}^{+}$content in leaves of the 'Toscano folha de alface' genotype $\left(0.126 \mathrm{mmol} \mathrm{g}^{-1} \mathrm{DM}\right)$ was $64 \%$ lower than the mean leaf content of the other genotypes $(0.348$ mmol g-1 DM). In this way, it can be inferred that there was a restriction in the transport of $\mathrm{Na}^{+}$to the leaves, with a retention of these ions in the roots of the genotype. This might explain, at least in part, the greater tolerance of this genotype to saline stress since such restriction inhibits $\mathrm{Na}^{+}$accumulation at toxic levels in leaves (Munns \& Tester, 2008). 


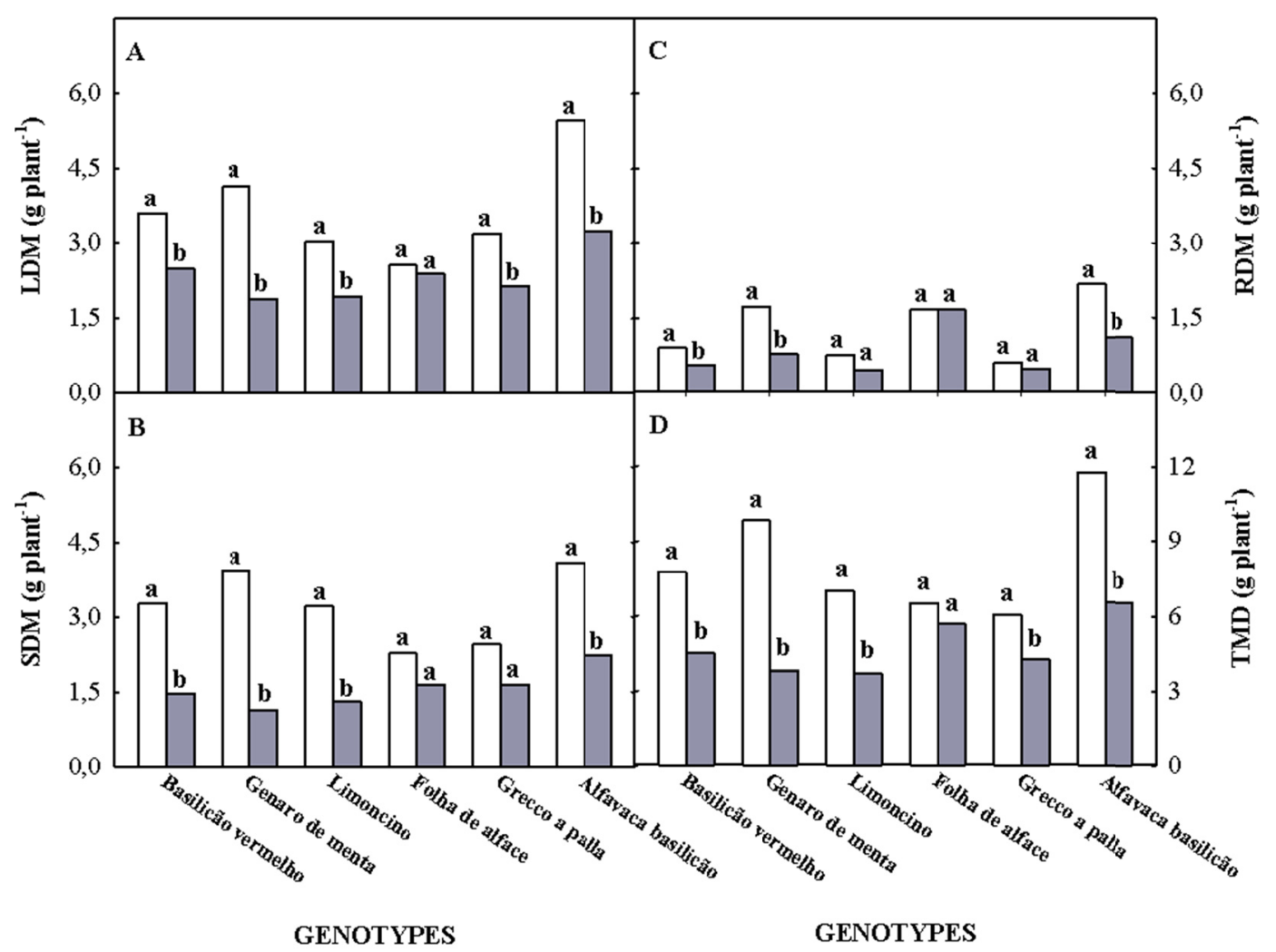

Figure 4. Dry mass of leaves - LMD (A), stem - SDM (B), roots RDM (C) and total- TDM (D) of six basil genotypes after 17 days of treatment in nutrient solution containing 0 ( $\square)$ or $80 \mathrm{mM} \mathrm{NaCl}(\square)$

Note. For each genotype, averages followed by the same letters do not differ from each other by the Scott Knott test at 0.05 probability.

Salinity significantly increased $\mathrm{Na}^{+}$and $\mathrm{Cl}^{-}$contents independently of the plant organ or genotype (Figure 5). The highest increments in $\mathrm{Cl}^{-}$per levels of $\mathrm{NaCl}$ in the nutrient solution were observed in the 'Gennaro' genotype of peppermint, both leaves ( 7 times) and stem ( 5 times) and roots $(9$ times). For the same ion, the smallest increments were observed in the 'Limoncino' genotype, which represented 2.09, 2.46 and 3.23 fold, in leaves, stem and roots, respectively (Figures 5D, 5E and 5F).

The greater increase in $\mathrm{Cl}^{-}$levels in the organs of the 'Gennaro' genotype of peppermint may partly explain the sensitivity of the genotype to saline stress associated with a greater reduction of DM of this genotype. These data corroborate with the results of Assay I where there was greater reduction of DM in the tissues with greater $\mathrm{Cl}^{-}$ accumulation. Ever since accumulated concentrations of $\mathrm{Cl}^{-}$can cause severe damage to plant tissues (Munns \& Tester, 2008).

The $\mathrm{K}^{+}$presented higher content in the leaves, in relation to the other organs of the plant. The effect of saline stress over $\mathrm{K}^{+}$contents varied between genotypes and between parts of plants. In the leaves, salinity increased $\mathrm{K}^{+}$levels in the 'Alfavaca basilicão vermelho' (16\%), 'Gennaro de menta" (22\%), 'Toscano folha de alface' $(13 \%)$ and 'Alfavaca basilicão' (5\%) genotypes, but, it did not affect the others (Figure $5 \mathrm{G})$. In the stem, the $\mathrm{K}^{+}$ content increased in the 'Grecco à palla' (42\%), decreased in the 'Alfavaca basilicão vermelho' $(30 \%)$, 'Gennaro de menta' (13\%) and 'Alfavaca basilicão' (14\%) genotypes and unchanged in the 'Limoncino" and "Toscano folha de alface' genotypes (Figure $5 \mathrm{H}$ ). In the roots, saline stress did not alter $\mathrm{K}^{+}$contents in the studied genotypes (Figure 5I).

In contrast to what was observed for the $\mathrm{Na}^{+}$ion, it can also be observed in Figure $5 \mathrm{G}$ that the foliar $\mathrm{K}^{+}$contents in the 'Toscano folha de alface' genotype (4.266 $\left.\mathrm{mmol} \mathrm{g}^{-1} \mathrm{DM}\right)$ were $26 \%$ higher than the mean foliar concentration of the other genotypes (3.374 mmol g-1 DM). Azevedo Neto and Silva (2015) report that the mechanism for the adequate maintenance of the $\mathrm{K}^{+}$content in the vegetal tissues, under saline condition, is in part dependent on the selectivity of $\mathrm{K}^{+}$for the shoot, as well as the $\mathrm{Na}^{+}$compartmentation. 


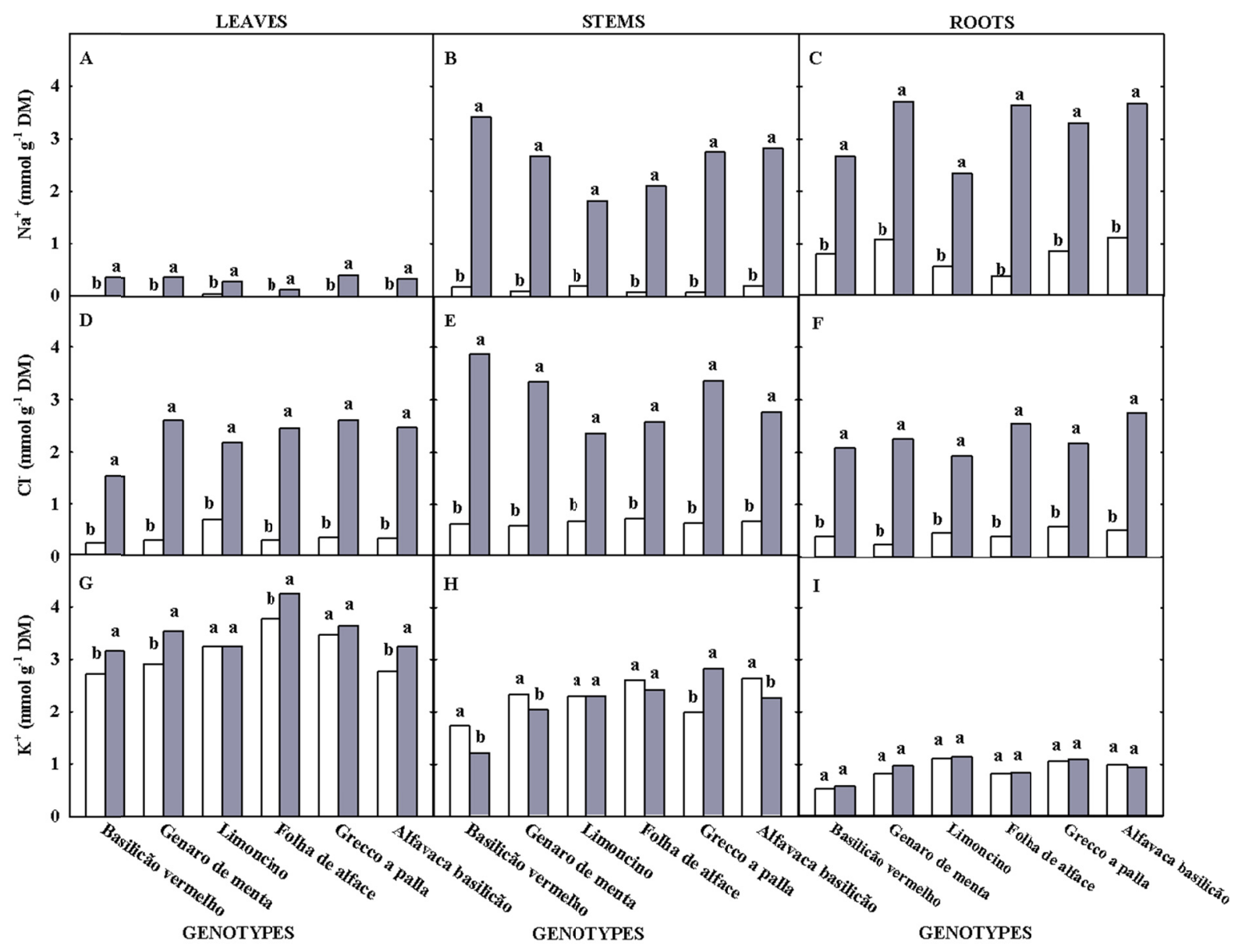

Figure 5. Contents of sodium $-\mathrm{Na}^{+}(\mathrm{A}, \mathrm{B}$ and $\mathrm{C})$, chloride $-\mathrm{Cl}^{-}(\mathrm{D}, \mathrm{E}$ and $\mathrm{F})$ and potassium $-\mathrm{K}^{+}(\mathrm{G}, \mathrm{H}$ and $\mathrm{I})$ in mmol g${ }^{-1}$ leaf (LDM), stems (SDM) and roots (RDM) of six basil genotypes after 17 days of treatment in nutrient solution containing 0 ( $\square$ ) or $80 \mathrm{mM} \mathrm{NaCl}(\square)$

Note. Means followed by same letters between saline levels do not differ from one another by the Scott Knott test at 0.05 probability.

$\mathrm{K}^{+}$is essential for ionic homeostasis and protection of the physiological mechanism, which favors photosynthesis and other physiological functions of plants (Munns, 2002). Ionic homeostasis is primordial for the physiology of living cells by maintaining low cellular concentrations of toxic ions and accumulating essential ions (Zhu, 2003). Such equilibrium results in maintenance of turgescence pressure, cell division, growth and biomass production, even under saline conditions. Thus, these data suggest that the increase in $\mathrm{K}^{+}$concentration in the leaves of the 'Toscano folha de alface' genotype is directly related to its greater tolerance to saline stress. It can still be suggested that, for all genotypes, there were no salinity-induced disturbances in $\mathrm{K}^{+}$uptake and translocation, since the contents of this ion in roots and leaves were not altered or increased with saline stress.

The levels of chlorophyll $a$ (CHL $a$ ) and chlorophyll $b$ (CHL $b)$ in the studied genotypes were not altered by saline stress, except for the CHL $b$ content in the 'Alfavaca basilicão vermelho' genotype, which decreased by $35 \%$ (Figures $6 \mathrm{~A}$ and $6 \mathrm{~B}$ ). Thus, the $\mathrm{CHL} a / \mathrm{CHI} b$ ratio showed a significant increase of $39 \%$ only in this genotype (Figure 6C). In relation to carotenoids, the levels of these pigments decreased with salinity in 'Alfavaca basilicão vermelho' (19\%), 'Limoncino' (17\%) and 'Toscano folha de alface' (16\%), increased in 'Grecco a palla' (114\%) and were not altered in 'Gennaro de menta' and 'Alfavaca basilicão' (Figure 6D).

According to Heidari (2012), saline stress reduces the growth and the content of photosynthetic pigments in sensitive plants and increases in tolerant plants. However, considering that the changes in the chlorophyll content of the 'Toscano folha de alface' (tolerant) and 'Gennaro de menta' (sensitive) genotypes were similar and that of carotenoids increased in 'Gennaro de menta', these results indicate that the pigment contents showed no relation 
with tolerance to salinity and should not be considered as good biochemical markers for tolerance to saline stress in these basil genotypes.

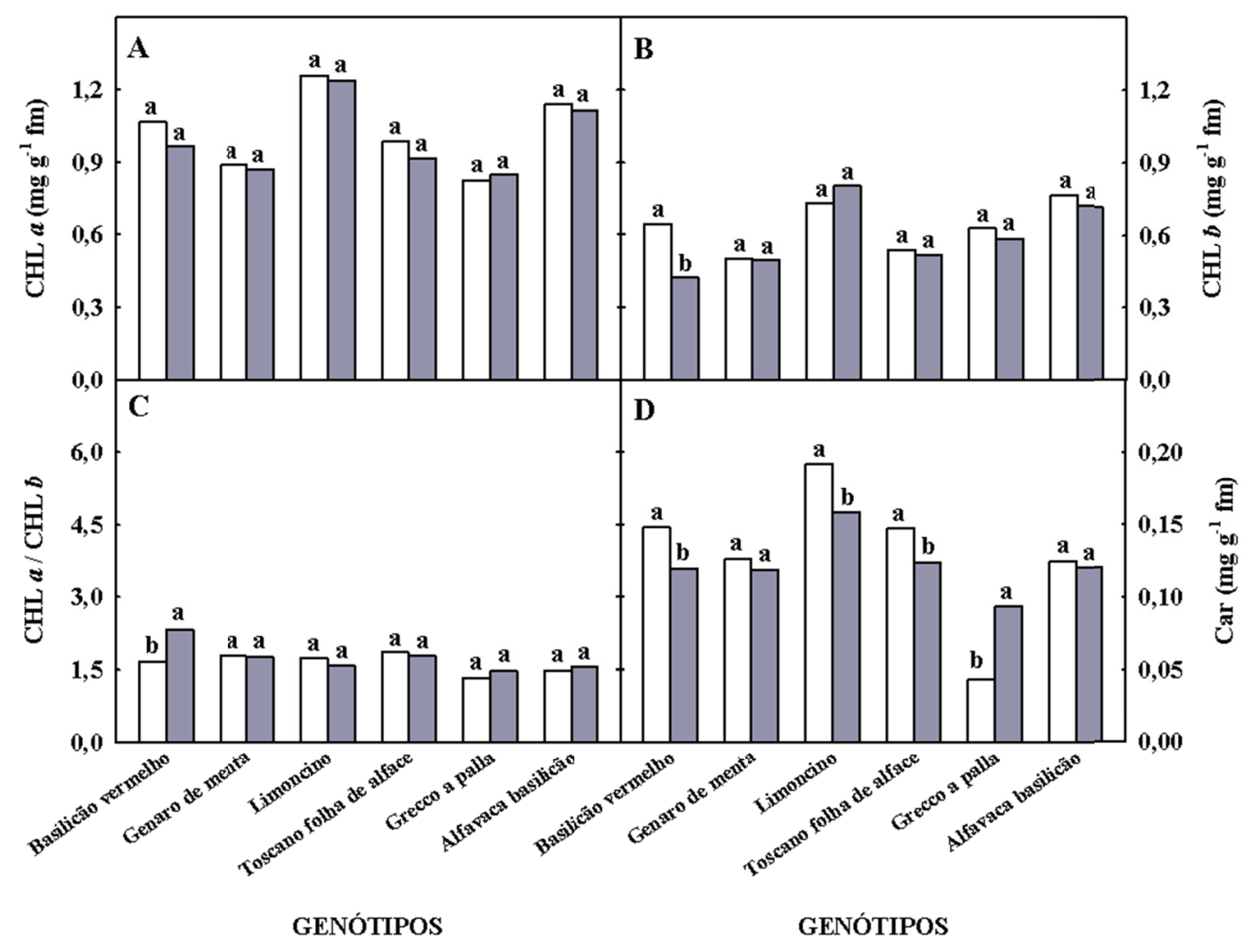

Figure 6. Concentration of Chlorophyll $a(\mathrm{CHL} a)$, Chlorophyll $b$ (CHL $b)$ and Carotenoids (Car) in leaves and $\mathrm{CHL} a$ and $\mathrm{CHL} b(\mathrm{CHL} a / \mathrm{CHL} b)$ ratio of six basil genotypes after 17 days of treatment in nutrient solution containing $0(\square)$ or $80 \mathrm{mM} \mathrm{NaCl}(\square)$

Note. For each genotype, averages followed by the same letters do not differ from each other by the Scott Knott test at 0.05 probability.

Changes in the relative water content (RWC) and absolute integrity percentage (AIP) are shown in Figure 7. Salinity caused a small reduction in the RWC of the genotypes 'Limocino' (9\%) and 'Grecco a palla' (8\%) (Figure 7A). Salinity decreased, averaging $37 \%$ of the PAI of all genotypes, with the exception of the 'Toscano folha de alface', which was not affected by stress (Figure 7B). Considering that the 'Toscano folha de alface' genotype was also the most tolerant to saline stress, when evaluated for its biomass production, the results of this study suggest that the estimation of membrane integrity expressed by AIP can be used as a physiological indicator in the identification of basil genotypes tolerant to saline stress.

According to Gupta and Huang (2014), salinity tolerance characteristics involve complex responses at molecular, cellular, metabolic, and physiological levels throughout the plant. Thus, evaluations of the morphological and physiological characteristics associated with yield provide a greater sensitivity in the identification of salinity tolerant plants (Ashraf, 2004). This author further emphasizes that the use of physiological attributes as salinity tolerance markers depends on how strong is the relationship of these markers to plant responses and it is probably more effective than selections based on individual markers.

The photosynthetic pigment contents and the relative water content were not good indicators of salinity tolerance for basil. On the other hand, the production of dry mass, the accumulation of inorganic solutes and the percentage of absolute integrity, stand out as good indicators of tolerance to saline stress among the studied genotypes. The higher accumulation of $\mathrm{K}^{+}$and a lower accumulation of $\mathrm{Na}^{+}$in the leaves of the 'Toscano folha de alface' genotype plays a key role in maintaining the integrity of the cell membranes in this genotype. The 
'Toscano folha de alface' genotype is more tolerant to salinity and the 'Gennaro de menta' more sensitive when compared to each other.

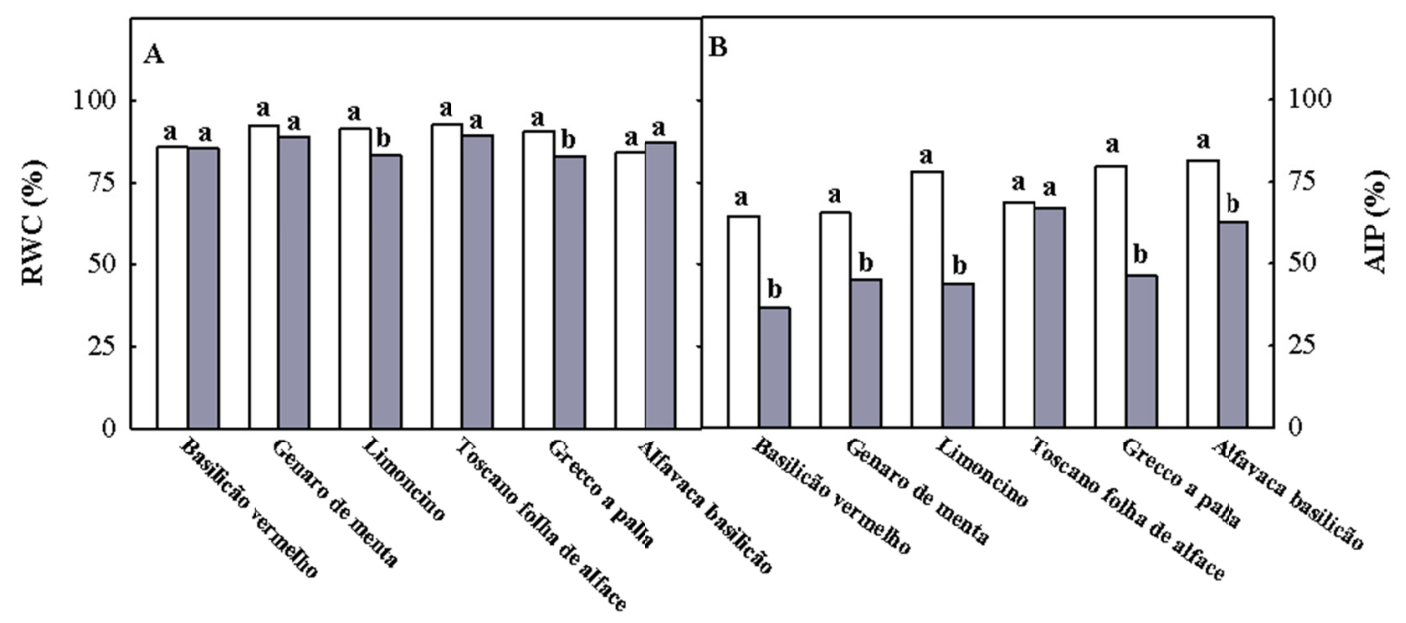

GENOTYPES

GENOTYPES

Figure 7. Relative water content in leaves (RWC) and absolute integrity percentage (AIP) off cell membranes in six six basil genotypes after 17 days of treatment in nutrient solution containing 0 ( $\square$ ) or $80 \mathrm{mM} \mathrm{NaCl}(\square)$

Note. For each genotype, means followed by the same letters do not differ from each other by the Scott Knott test at 0.05 probability.

\section{References}

Ashraf, M. (2004). Some important physiological selection criteria for salt tolerance in plants. Flora, 199, 361-376. https://doi.org/10.1016/j.biotechadv.2008.09.003

Atkin, O. K., \& Macherel, D. (2009). The crucial role of plant mitochondria in orchestrating drought tolerance. Annals of Botany, 103, 581-597. https://doi.10.1093/aob/mcn094

Ayers, R. S., \& Westcot, D. W. (1999). A qualidade de água na agricultura (2nd ed.). Campina Grande, PB: UFPB, FAO.

Azevedo Neto, A. D., \& Silva, E. C. (2015). Physiology and biochemistry of salt stress tolerance in plants. In U. Chakraborty \& B. Chakraborty (Eds.), Abiotic stresses in crop plants (pp. 81-101). Wallingford, OX: CABI. https://doi.org/10.1079/9781780643731.0081

Azevedo Neto, A. D., Pereira, P. P. A., Costa, D. P., \& Santos, A. C. C. (2011). Fluorescência da clorofila como uma ferramenta possível para seleção de tolerância à salinidade em girassol. Revista Ciência Agronômica, 42, 893-897. https://doi.org/10.1590/S1806-66902011000400010

Barbieri, G., Vallone, S., Orsini, F., Paradiso, R., Pascale, S., Negre-Zakharov, F., \& Maggio, A. (2012). Stomatal density and metabolic determinants mediate salt stress adaptation and water use efficiency in basil (Ocimum basilicum L.). Journal of Plant Physiology, 169, 1737-1746. https://doi.org/10.1016/j.jplph.2012.07.001

Barr, H. D., \& Weatherley, P. E. (1962). A re-examination of the relative turgidity technique for estimating water deficit in leaves. Australian Journal of Biology Science, 15, 413-428. https://doi.org/10.1071/BI9620413

Bharti, N., Barnawal, D., Wasnik, K., Tewari, S. K., \& Kalra, A. (2016). Co-inoculation of Dietzia natronolimnaea and Glomus intraradices with vermicompost positively influences Ocimum basilicum growth and resident microbial community structure in salt affected low fertility soils. Applied Soil Ecology, 100, 211-225. https://doi.org/10.1016/j.apsoil.2016.01.003

Bione, M. A. A., Paz, V. P. S., Silva, F., Ribas, R. F., \& Soares, T. M. (2014). Crescimento e produção de manjericão em sistema hidropônico NFT sob salinidade. Revista Brasileira de Engenharia Agrícola e Ambiental, 18, 1228-1234. https://doi.org/10.1590/1807-1929/agriambi.v18n12p1228-1234 
Cova, A. M. W., Azevedo Neto, A. D., Ribas, R. F., Gheyi, H. R., \& Menezes, R. V. (2016). Inorganic solute accumulation in noni (Morinda citrifolia L.) under salt stress during initial growth. African Journal of Agricultural Research, 11, 3347-3354. https://doi.org/10.5897/AJAR2016.11416

Faithfull, N. T. (2002). Methods in agricultural chemical analysis: A practical handbook. Wallingford, OX: CABI. https://doi.org/10.1079/9780851996080.0000

Farooq, M., Wahid, A., Kobayashi, N., Fujita, D., \& Basra, S. M. A. (2009). Plant drought stress: Effects, mechanisms and management. Agronomy for Sustainable Development, 29, 185-212. https://doi.org/ 10.1051/agro:2008021

Ferreira, D. F. (2011). Sisvar: A computer statistical analysis system. Ciência \& Agrotecnologia, Lavras, 35, 1039-1042. https://doi.org/10.1590/S1413-70542011000600001

Flowers, T. J., Munns, R., \& Colmer, T. D. (2015). Sodium chloride toxicity and the cellular basis of salt tolerance in halophytes. Annals of Botany, 115, 419-431. https://doi.org/10.1093/aob/mcu217

Furlani, P. R. (1998). Instrução para o cultivo de hortaliça de folha pela técnica de hidroponia- NFT. Campinas: Instituto Agronômico, (Boletim Técnico, 168).

Gupta, B., \& Huang, B. (2014). Mechanism of salinity tolerance in plants: Physiological, biochemical, and molecular characterization. International Journal of Genomics, 2014, 18-37. https://doi.org/10.1155/ 2014/701596

Heidari, M. (2012). Effects of salinity stress on growth, chlorophyll content and osmotic components of two basil (Ocimum basilicum L.) genotypes. African Journal of Biotechnology, 11, 379-384. https://doi.org/ 10.5897/AJB11.2572

Jones Júnior, J. B. (2001). Laboratory guide for conducting soil tests and plant analysis. Boca Raton, FL: CRC Press. https://doi.org/10.1201/9781420025293

Li, B., Tester, M., \& Gilliham, M. (2017). Chloride on the move. Trends in Plant Science, 22, 236-248. https://doi.org/10.1016/j.tplants.2016.12.004

Lichtenthaler, H. K., \& Buschmann, C. (2001). Chlorophylls and carotenoids: Measurement and characterization by UV-VIS spectroscopy. Current Protocols in Food Analytical Chemistry, F4.3.1-F4.3.8. https://doi.org/ 10.1002/0471142913.faf0403s01

Maas, E. V., \& Hoffman, G. J. (1977). Crop salt tolerance: Current assessment. Journal of the Irrigation and Drainage Division of ASCE. 103, 115-134.

Marschner, H. (2012). Mineral nutrition of higher plants (3rd ed.). London, UK: Elsevier. https://doi.org/ 10.1016/B978-0-12-384905-2.00015-7

Munns, R. (1993). Physiological processes limiting plant growth in saline soil: Some dogmas and hypotheses. Plant, Cell and Environment, 16(2), 15-24. https://doi.org/10.1111/j.1365-3040.1993.tb00840.x

Munns, R. (2002). Comparative physiology of salt and water stress. Plant, Cell and Environment, 25, 239-250. https://doi.org/10.1046/j.0016-8025.2001.00808.x

Munns, R., \& Tester, M. (2008). Mechanisms of salinity tolerance. Annual Review of Plant Biology, 50, 651-681. https://doi.org/10.1146/annurev.arplant.59.032607.092911

Niknam, S. R., \& McComb, J. (2000). Salt tolerance screening of selected Australian woody species: A review. Forest Ecology and Management, 139, 1-19. https://doi.org/10.1016/S0378-1127(99)00334-5

Ning, J. F., Cui, L. H., Yang, S. H., Ai, S. Y., Li, M. J., Sun, L. L., .. Zeng, Z. B. (2015). Basil ionic responses to seawater stress and the identification of gland salt secretion. The Journal of Animal \& Plant Sciences, 25, $131-138$.

Odjegba, J. V., \& Chukwunwike, C. I. (2012). Physiological responses of Amaranthus hybrids L. under salinity stress. Indian Journal of Innovations and Developments, 1, 742-748.

Parida, A. K., \& Das, A. B. (2005). Salt tolerance and salinity effects on plants: A review. Ecotoxicology and Environmental Safety, 60, 324-349. https://doi.org/10.1016/j.ecoenv.2004.06.010

Paulus, D., Dourado Neto, D., Frizzone, J. A., \& Soares, T. M. (2010). Produção e indicadores fisiológicos de alface sob hidroponia com água salina. Horticultura Brasileira, 28, 29-35. https://doi.org/10.1590/S010205362010000100006 
Pimentel, C., Sarr, B., Diouf, O., Aboud, A. C. S., \& Roy-Macauley, H. (2002). Tolerância protoplasmática foliar à seca, em dois genótipos de caupi cultivadas em campo. Revista de Ciências da Vida, 22(1), 07-14.

Prasad, A., Lal, R. K., Chattopadhyay, A., Yadav, V. K., \& Yadav, A. (2007). Response of basil species to soil sodicity stress. Communications in Soil Science and Plant Analysis, 38, 2705-2715. https://doi.org/10.1080/ 00103620701662943

Santos, A. N., Soares, T. M., Silva, E. F. F., Silva, D. J. R., \& Montenegro, A. A. A. (2010). Cultivo hidropônico de alface com água salobra subterrânea e rejeito da dessalinização em Ibimirim, PE. Revista Brasileira de Engenharia Agrícola e Ambiental, 14, 961-969. https://doi.org/10.1590/S1415-43662010000900008

Sgherri, C., Cecconami, S., Pinzino, C., Navari-Izzo, F., \& Izzo, R. (2010). Levels of antioxidants and nutraceuticals in basil grown in hydroponics and soil. Food Chemistry, 123, 416-422. https://doi.org/ 10.1016/j.foodchem.2010.04.058

Shabala, S., \& Mackay, A. (2011). Ion transport in halophytes. Advances in Botanical Research, 57, 151-199. https://doi.org/10.1016/B978-0-12-387692-8.00005-9

Silveira, J. A. G., Silva, S. L. F., Silva, E. N., \& Viégas, R. A. (2010). Mecanismos biomoleculares envolvidos com a resistência ao estresse salino em plantas. In H. R. Gheyi, N. S. Dias, \& C. F. Lacerda (Eds.), Manejo da salinidade na agricultura: Estudos básicos e aplicados (pp. 161-180). Fortaleza, CE: INCTSal.

Tavakkoli, E., Rengasamy, P., \& McDonald, G. K. (2010). High concentrations of $\mathrm{Na}^{+}$and $\mathrm{Cl}^{-}$ions in soil solution have simultaneous detrimental effects on growth of faba bean under salinity stress. Journal of Experimental Botany, 61, 4449-4459. https://doi.org/10.1093/jxb/erq251

Zhu, J. K. (2003). Regulation of ion homeostasis under salt stress. Current Opinion in Plant Biology, 6, 441-445. https://doi.org/10.1016/S1369-5266(03)00085-2

\section{Copyrights}

Copyright for this article is retained by the author(s), with first publication rights granted to the journal.

This is an open-access article distributed under the terms and conditions of the Creative Commons Attribution license (http://creativecommons.org/licenses/by/4.0/). 